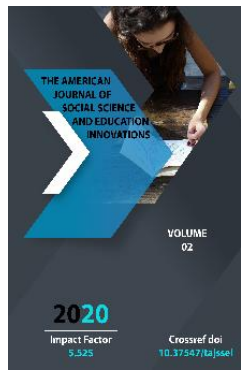

\title{
Age And Gender Features Of Motivational Readiness Of Children For School Education
}

\author{
Khodjakulova Dilorom Imamovna \\ Candidate Of Psychological Sciences, Associate Professor Tashkent Institute Of Textile And \\ Light Industry, Uzbekistan
}

Copyright: Original content from this work may be used under the terms of the creative commons attributes 4.o licence.

\section{ABSTRACT}

The article analyzes the concept of motivational readiness for schooling, reveals the structure of motivational readiness and the student's internal position as one of the most important neoplasms of the motivational sphere in preschool age, presents the results of an empirical study of age and gender characteristics of motivational readiness of children for schooling.

\section{KEYWORDS}

Motivation, motivational readiness for schooling, educational motives, the internal position of the student.

\section{INTRODUCTION}

One of the fundamental components of psychological readiness for schooling is the child's motivational readiness for school. An important and at the same time insufficiently studied aspect of the problem of motivational readiness for schooling is to take into account the age and sex characteristics of the motivational sphere of children of preschool age.

It is known that in preschool age there are differences between boys and girls, which can be reflected in the structure of motivational readiness for schooling. It is important to take into account these differences, to help the 
child discover the unique opportunities that are given to him by virtue of gender. Reducing the age of schooling to six years is also an acute and urgent problem, as it leads to the fact that many children who enter the school are completely unprepared for it. Psychologists say that if the child does not have motives for learning, he will be quite hard to get used to the new conditions, to the teacher, to the team of peers, and he will not be well enough to perceive the new school material, which will lead to school maladaptation. Therefore, the analysis of age and sex characteristics of the motivational readiness of children to study at school is relevant.

\section{MATERIAL AND METHODS}

Motivational readiness for schooling implies the presence of a future first-grader, a system of motives that provide a high interest in learning at school [2]. In other words, motivational readiness includes: positive ideas about the school, the desire to go to school to learn, to be able to learn a lot, and also the formed position of the student [1]. Motivationally ready for schooling is considered to be a preschooler, whom the school attracts not by its external side (attributes), but by the opportunity to acquire new knowledge, which implies the development of cognitive interests.

Towards the end of preschool age, the formation of a central qualitatively new personal education - the internal position of the student [3]. L. I. Bozhovich [2] noted that the internal position is the core of the personality of a preschooler of six to seven years, it connects and unites other personality structures, combines, integrates all the lines of previous personal development, while being the most significant indicator of readiness child to school. L.I. Bozhovich identifies two groups of motives for teaching: first, broad social motives that are associated with the relationship of the preschooler to the surrounding social reality, namely, the need of the child to take a certain position in society; secondly, cognitive motives that reflect a connection with intellectual activity and are determined by a direct interest in activities [2].

These motives L.I. Bozovic considers as the main content of the student's internal position. The structure of the student's internal position includes the following components: a certain attitude of the preschooler to the school, to the teacher and educational activities, to peers, relatives and friends, as well as to oneself.

\section{RESULTS AND DISCUSSION}

The purpose of our study was to study the agesex characteristics of motivational readiness of children for schooling. The study involved children of two senior groups and two groups preparing for school - 40 and 37 people, respectively. For the diagnosis of age and sex features of motivational readiness for schooling, the following methods were used: the method of diagnosis of the leading motive of MR Ginzburg "Motives of learning", the method of diagnosing the degree of formation of motivational readiness T.A. Nezhnova "Conversation about the school" [4].

Obtained diagnostic data according to M.R. Ginzburg speaks about the difference in the severity of leading motives in children of older and preparatory groups for school. As adequate motives, they call the educational one, which is characterized by a desire to study and attend school, social - based on the awareness of social significance and the need for learning, as well as positional, which is associated with interest in the external 
attributes of school life and the student's position. These motives are manifested in the preparatory groups for the school as follows: the academic is $57 \%$, social $-24 \%$ and positional is observed in $15 \%$. And in older groups, these motives are represented by a very low percentage, namely: educational and positional $-2 \%$, social $-7 \%$. The remaining three motives - the game, which manifests itself in the desire to only play, walk, chat with children; external, characterized by its own unwillingness to go to school, and attend it only under duress; and the mark motive, characterized by the child's desire to go to school to earn the fives that adults praise for, is characteristic of older children. So, the game motive dominates in $62 \%$ of children, the motive of the mark in $21 \%$, the external in $7 \%$. In children in preparatory groups for schools, this percentage ratio is much lower: the motive mark and game were found in $2 \%$ of the children surveyed, no external motive was found. Based on this, we can conclude that the motivational readiness for school in children of older groups has not yet been formed. And in preparatory groups motivational readiness is formed adequately.

When analyzing gender differences in children of the two groups, according to the method of M.R. Ginzburg, some patterns were also discovered. We found that in the older groups the dominant motive among boys was only a game motive - $86 \%$, while for girls, equally, the leading motive was a game motive and a mark motive - $32 \%$ each. In the preparatory groups for school, we found that in girls the leading motive is the educational one $-77 \%$, and in boys - the social one - $45 \%$. Thus, we can judge the difference in motives between boys and girls of the same age group.
After processing the data obtained by the method of T. A. Nezhnova "Conversation about the school", we can talk about the differences between the results of diagnosis in children of older and preparatory to school groups. So, in older groups, a low degree of formation of motivational readiness for school, which is characterized by a child's desire to go to school, but while maintaining a preschool lifestyle, was found in $68 \%$, and in children in preparatory groups, this figure was only $5 \%$. A high degree of motivational readiness, which indicates the formation of the student's internal position, was $52 \%$ in children of preparatory school groups, and $5 \%$ in older groups. The average degree of formation was found in children of senior and preparatory groups in $27 \%$ and $43 \%$, respectively. Based on these data, we can conclude that a higher degree of formation of motivational readiness in children of preparatory groups for school and a lower degree in children of older groups.

In the analysis of gender differences in children of the two groups, according to the method of T.A. Nezhnova, the following conclusions were made. In older groups, the difference between the degree of formation of motivational readiness in boys and girls is not significant. In children in preparatory groups, the difference is more noticeable. So, in boys, a low level is observed in $11 \%$, while in girls it is absent. The average level is observed in $56 \%$ of boys, in girls in $35 \%$. A high level of formation of motivational readiness is observed in 33\% of boys and in 65\% - in girls. Based on the foregoing, we can argue that in children of pre-school groups there are gender differences, which manifest themselves in a higher degree of motivational readiness in girls than in boys.

\section{CONCLUSIONS}


Statistical processing of data by the Pearson criterion showed the presence of a high-level statistical connection between the degree of formation of motivational readiness for schooling and the leading motive for learning in children. Statistical processing of data using Student's t-test showed significant severity of gender differences in the leading motive in children of senior and preparatory groups, as well as the degree of formation of motivational readiness in children of preparatory groups, gender differences in the degree of formation of motivational readiness in children of senior groups, according to t- Student criterion, had an indefinite severity. The study confirms the correctness of the hypothesis that there are gender and age differences in the structure of motivational readiness for schooling in children of senior and preparatory groups of preschool educational institutions. The results obtained in this study can be the basis for the development of practical recommendations for optimizing the process of formation of motivational readiness for schooling, taking into account age and gender characteristics; can be used in building programs for the psychological preparation of children for school.

\section{REFERENCES}

1. Bozovic L.I. Personality and its formation in childhood. - SPB .: Peter, 2009 -- 400 s.

2. Bozhovich L.I. Problems of personality formation / Ed. DI. Feldstein. - M.: Institute of Practical Psychology, 1997. - 352 p.

3. Gonina O.O. Psychology: a short course of lectures for bachelors. 2014. $-M .:$ Publishing House Sputnik + LLC. - 102 p.
4. Nizhegorodtseva N.V., Shadrikov V.D. Psychological and pedagogical readiness of the child for school. - M .: Vlados, 2001 -- 256 p.

5. Rustamiy, S. (2018). Typological peculiarties of science of balaghah, rhetoric and stylistics. The Light of Islam, 2018(1), 16.

6. Rustamiy, S. A. (2020). Content of components of the science balagat. ACADEMICIA: An International Multidisciplinary Research Journal, 10(10), 1332-1337.

7. Axmedovna, J. N., Gapporovna, S. M., Rozmatovna, A. O., \& Tashkent, U. Z. B. E. K. I. S. T. A. N. (2019). THE IMPORTANCE OF NEEDS ANALYSIS IN TEACHING ESP. European Journal of Research and Reflection in Educational Sciences Vol, 7(11).

8. Sodirjonov, M. M. (2020). Some Thoughts On The Evolution Of Approaches To The Concept Of Human Capital. The American Journal of Social Science and Education Innovations, 2(08), 144-150. 